๑ К КОРЕЦКАЯ Н. М., ЭЛЯРТ В. Ф., БЕЛОУСОВА Ю. Н.

УАК 616.24-002.5:615.015.8:615.281.9:343.81(571.51)

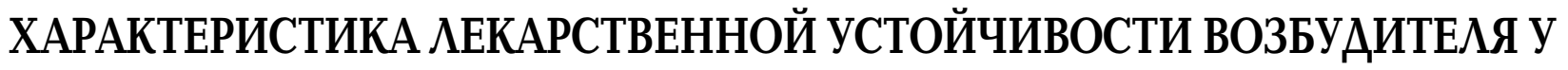

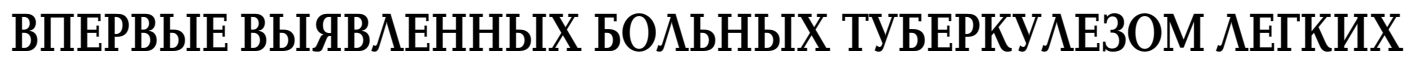 В ПЕНИТЕНЦИАРНЫХ УЧРЕЖАЕНИЯХ КРАСНОЯРСКОГО КРАЯ
}

\author{
Н. М. Корецкая ${ }^{1}$, В. Ф. Элярт ${ }^{2}$, Ю. Н. Белоусова ${ }^{3}$
}

${ }^{1}$ ГБОУ ВПО Красноярский государственный медицинский университет имени проф. В. Ф. Войно-Ясенецкого Министерства здравоохранения РФ, ректор - А. м. н., проф. И. П. Артюхов; кафедра туберкулеза с курсом ПО, зав. - А. м. н., проф. Н. М. Корецкая; ${ }^{2}$ Медико-санитарная часть №24 Федеральной службы исполнения наказаний

России, г. Красноярск, начальник - В. Ф. Элярт; ${ }^{3}$ Туберкулезная больница-1 Медико-санитарной части № 24 Федеральной службы исполнения наказаний России, г. Красноярск, гл. врач - А. С. Карелин.

Цель исслеgования. Изучение частоты, спектра и структуры первичной лекарственной устойчивости МБТ у больных туберкулезом легких, впервые выявленных в условиях пенитенциарной системы Красноярского края и нахоgившихся на стационарном лечении в меgицинском учрежgении ФСИН России.

Материалы и метоgы. Аекарственная устойчивость штаммов МБТ опреgелена у 102 больных станgартным непрямым методом абсолютных концентраций.

Результаты. Первичная лекарственная устойчивость МБТ имела место у 70,6\% больных; преоблаgала множественная $\Lambda \mathrm{Y}(48,1 \%)$.

Заключение. Необхоgимо применение ускоренных метоgов опреgеления АУ МБТ, позволяющих назначать аgекватную терапию в более короткие сроки.

Ключевые слова: туберкулез, лекарственная устойчивость, пенитенциарная система.

\section{CHARACTERISTICS OF DRUG RESISTANCE IN NEWLY DIAGNOSED PATIENTS WITH PULMONARY TUBERCULOSIS IN PENITENTIARY INSTITUTIONS OF KRASNOYARSK REGION}

\author{
N. M. Koretskaya ${ }^{1}$, V. F. Elyart ${ }^{2}$, Yu. N. Belousova ${ }^{3}$ \\ ${ }^{1}$ Krasnoyarsk State Medical University named after. Prof. V.F. Voyno-Yasenetsky, \\ ${ }^{2}$ Federal State Health Agency Medical Unit №24 of Russia Federal Service for Execution of Punishment, ${ }^{3}$ Tubercular \\ Hospital-1 Federal State Health Agency Medical Unit № 24 of Russia Federal Service for Execution of Punishment
}

The aim of the research. To study the frequency, spectrum and structure of primary drug resistance in patients with pulmonary tuberculosis, first identified in terms of the penitentiary system of the Krasnoyarsk Region and were hospitalized in a medical facility of FSIN Russia.

Materials and methods. Drug resistance MBT strains detected in 102 patients with standard indirect method of absolute concentrations.

Results. Primary drug resistance occurred in $70.6 \%$; was dominated multiple DR (48.1\%).

Conclusion. Requires accelerated methods for determining the LU MBT, allows to have adequate therapy in a shorter time. Keywords: tuberculosis, drug resistance, the penitentiary system.

\section{Введение}

Эпидемиологическая ситуация по туберкулезу в пенитенциарных учреждениях России остается напряженной, несмотря на значительное снижение показателей заболеваемости и повышение эффективности лечения впервые выявленных больных [3]. В значительной мере это связано с высоким уровнем распространения и ростом лекарственной устойчивости микобактерий туберкулеза (МБТ), и прежде всего множественной, среди больных из числа спецконтингента учреждений Федеральной службы исполнения наказаний (ФСИН) $[3,5,10]$. Эпидемиологическое значение туберкулеза с множественной лекарственной устойчивостью возбудителя особо велико, ибо такой специфический процесс сопровождается массивным бактериовыделением значительно чаще, чем процесс, вызванный возбудителем без лекарственной резистентности [7].

Наличие у больных туберкулезом легких лекарственной устойчивости МБТ имеет не только научное, клиническое и эпидемиологическое, но и большое экономическое значение, так как лечение таких больных требует применения антибактериальных препаратов резервного ряда, вызывающих серьезные побочные реакции, оно более длительное и обходится намного дороже $[2,3,7,10]$. 
В связи с этим одной из важных задач фртизиатрии в условиях пенитенциарной системы является выявление больных туберкулезом легких с бактериовыделением и особенно раннее выявление пациентов, выделяющих лекарственно-устойчивые штаммы МБТ, а также назначение им адекватного лечения [7,9].

Первичная (экзогенная) лекарственная устойчивость МБТ свидетельствует о заражении резистентным штаммом МБТ и она характеризует состояние микобактериальной популяции, циркулирующей в конкретном регионе [7]. Показатели первичной лекарственной устойчивости МБТ важны для оценки степени напряженности эпидемической ситуации, выработки стандартных режимов химиотерапии $[7,10]$. В этой связи изучение региональной первичной лекарственной устойчивости популяции МБТ в лечебном учреждении ФСИН представляется нам актуальной проблемой.

Целью исследования явилось изучение частоты, спектра и структуры первичной мекарственной устойчивости МБТ у больных туберкулезом легких, впервые выявленных в условиях пенитенциарной системы Красноярского края и находившихся на стационарном лечении в медицинском учреждении ФСИН России.

\section{Материалы и методы}

Материалом исследования явились картограммы 102 больных туберкулезом легких, находившихся на стационарном лечении в туберкулезной больнице-1 МСЧ №24 ФСИН России в 2012 году.

Все больные были впервые выявлены и являлись бактериовыделителями. У всех больных бактериовыделение было установлено путем посева мокроты на питательную среду Левенштейна-Йенсена.

Исследование лекарственной чувствительности штаммов МБТ к препаратам основного (изониазиду, рифампицину, этамбутолу и стрептомицину) и резервного ряда (этионамиду, канамицину, ПАСК и фторхинолонам) проводили стандартным непрямым методом абсолютных концентраций. Определяли частоту лекарственной устойчивости, ее структуру и спектр.

В структуре лекарственной устойчивости МБТ учитывали монорезистентность, полирезистентность (устойчивость к Авум препаратам и более, за исключением одновременной устойчивости к изониазиАу и рифампицину); множественную лекарственную устойчивость - устойчивость по крайней мере к изониазиду и рифампицину, независимо от наличия или отсутствия резистентности к другим препаратам, а также широкую лекарственную устойчивость сочетание множественной лекарственной устойчивости с резистентностью к фтторхинолонам и одному из инъекционных антибиотиков резервного ряда.

Статистическая обработка результатов исследования выполнена при помощи программы Microsoft Excel 2010. Описательная статистика Аля качественных признаков представлена абсолютными значениями, процентными долями и их стандартными ошибками.

\section{Результаты и обсуждение}

По результатам посева мокроты 102 больных лишь у $30(29,4 \pm 4,5 \%)$ выявлена лекарственно-чувствительная популяция МБТ, а лекарственно-устойчивая - у 72 $(70,6 \pm 4,5 \%)$. Структура лекарственной устойчивости МБТ

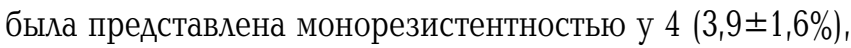
полирезистентностью - у $16(15,7 \% \pm 3,6)$, множественной лекарственной устойчивостью - у $49(48,2 \pm 5,0 \%)$ и широкой - у $3(2,9 \pm 1,7 \%)$ больных, то есть в половине случаев $(51,0 \pm 5,0 \%)$ имели место самые тяжелые виды кекарственной резистентности возбудителя.

Полирезистентность к препаратам основного ряда констатирована у $14(13,7 \pm 3,4 \%)$ больных, а к препаратам основного и резервного ряда она встречалась значительно реже - лишь у $2(2,0 \pm 1,4 \%)$ больных (табл. 1$)$.

Как видно из данных, приведенных в табл. 2, множественная лекарственная устойчивость МБТ к препаратам

Таблица 1

\section{Структура полирезистентности микобактерий туберкулеза} к противотуберкулезным препаратам (абс; \%; $M \pm m$ )

\begin{tabular}{|c|c|c|c|c|c|}
\hline $\begin{array}{c}\text { Противотуберулезные } \\
\text { препараты основного ряда }\end{array}$ & абс. & $\%$ & $\begin{array}{c}\text { Противотуберулезные } \\
\text { препараты резервного ряда }\end{array}$ & абс. & $\%$ \\
\hline $\mathrm{H}, \mathrm{S}$ & 9 & $8,8 \pm 2,8$ & H,S,Е,K & 2 & $2,0 \pm 1,4$ \\
\hline $\mathrm{R}, \mathrm{S}$ & 3 & $2,9 \pm 1,7$ & & & \\
\hline $\mathrm{H}, \mathrm{S}, \mathrm{E}$ & 2 & $2,0 \pm 1,4$ & & & \\
\hline Всего & 14 & $13,7 \pm 3,4$ & & 2 & $2,0 \pm 1,4$ \\
\hline
\end{tabular}

Таблица 2

\section{Структура множественной лекарственной устойчивости микобактерий туберкулеза к противотуберкулезным препаратам (абс; \%; $M \pm m)$}

\begin{tabular}{|c|c|c|c|c|c|}
\hline $\begin{array}{c}\text { Множественная } \\
\text { лекарственная устойчивость } \\
\text { к противотуберулезным } \\
\text { препаратам основного ряда }\end{array}$ & aбс. & $\%$ & $\begin{array}{c}\text { Множественная } \\
\text { лекарственная устойчивость } \\
\text { к противотуберулезным } \\
\text { препаратам резервного ряда }\end{array}$ & абс. & $\%$ \\
\hline H,R & 4 & $3,9 \pm 1,9$ & H,R,E,K & 9 & $8,8 \pm 2,8$ \\
\hline H,R,S & 21 & $20,6 \pm 4,0$ & H,R,S,K & 2 & $2,0 \pm 1,4$ \\
\hline H,R,E & 2 & $2,0 \pm 1,4$ & H,R,S,Et & 2 & $2,0 \pm 1,4$ \\
\hline H,R,S,E & 5 & $4,9 \pm 2,1$ & H,R,S,E,K,Pas & 1 & $1,0 \pm 1,0$ \\
\hline & & & H,R,S,K,Et & 2 & $2,0 \pm 1,4$ \\
\hline & & & H,R,S,Et,Ofl & 1 & $1,0 \pm 1,0$ \\
\hline Всего & 32 & $31,4 \pm 1,6$ & Bсего & 17 & $16,8 \pm 3,7$ \\
\hline
\end{tabular}


основного ряда констатирована у $32(31,4 \pm 1,6 \%)$ больных, при этом наибольший удельный вес $(20,6 \pm 4,0 \%)$ составила комбинация: изониазид, рифампицин и стрептомицин, то есть комбинация препаратов, входящая в режим химиотерапии впервые выявленных больных туберкулезом легких, на что указывают и другие авторы $[4,6]$.

Множественная лекарственная устойчивость МБТ, в сочетании с устойчивостью к препаратам основного и резервного ряда, установлена в $17(16,8 \pm 3,7 \%)$ случаев, то есть практически у каждого 6-го больного с лекарственнорезистентным туберкулезом. При этом наибольшую долю $(8,8 \pm 2,8 \%)$ составила следующая комбинация противотуберкулезных препаратов: изониазид, рифампицин, этамбутол и канамицин.

Наиболее тяжелый вид резистентности - широкая лекарственная устойчивость МБТ, обнаружена у $3(2,9 \pm 1,7 \%)$ больных: в двух случаях к сочетанию изониазида, рифампицина, стрептомицина, канамицина и офлоксацина, в одном - к сочетанию изониазида, рифампицина, стрептомицина, канамицина, офлоксацина, этионамида и ПАСК. Наличие множественной лекарственной устойчивости, сочетающейся с резистентностью к препаратам основного и резервного ряда, а также широкой лекарственной устойчивости ведет к наиболее тяжелому течению заболевания, более распространенным инфильтративнодеструктивным процессам $[4,6]$ и делает неэффективным IV режим химиотерапии [4]. По нашим данным, вышеуказанные виды резистентности наблюдались у $19,7 \pm 3,9 \%$, т.е. у каждого 5-го больного, что потребовало Аля данной категории больных применения таких методов лечения, повышающих его эффективность, как лимфотропное введение противотуберкулезных препаратов, к которым сохранилась лекарственная чувствительность МБТ; клапанная бронхоблокация, наложение пневмоперитонеума, проведение по возможности более раннего хирургического мечения.

\section{Спектр лекарственной устойчивости микобактерий туберкулеза к противотуберкулезным препаратам (абс; \%; $\mathrm{M \pm m})$}

\begin{tabular}{|c|c|c|}
\hline Препараты & абс. & $\%$ \\
\hline Изониазид (H) & 65 & $63,7 \pm 4,8$ \\
\hline Рифампицин (R) & 55 & $53,9 \pm 4,9$ \\
\hline Стрептомицин (S) & 57 & $55,9 \pm 4,9$ \\
\hline Этамбутол (E) & 21 & $20,6 \pm 4,0$ \\
\hline Канамицин (K) & 19 & $18,6 \pm 3,8$ \\
\hline Этионамид (Et) & 6 & $5,9 \pm 2,3$ \\
\hline ПАСК (Pas) & 2 & $2,0 \pm 1,4$ \\
\hline Офлоксацин (Of) & 4 & $3,9 \pm 1,6$ \\
\hline
\end{tabular}

Результаты изучения спектра первичной лекарственной устойчивости МБТ, приведенные в табл.3, показали, что наиболее высокий удельный вес лекарственной резистентности определялся к препаратам основного ряда: изониазиду - в $65(63,7 \pm 4,8 \%)$, стрептомицину - в 57 $(55,9 \pm 4,9 \%)$, рифампицину - в $55(53,9 \pm 4,9 \%) ;$ ниже, - к этамбутолу - в $21(20,6 \pm 4,0 \%)$ случае. Обращает на себя внимание тот факт, что частота лекарственной устойчивости МБТ к изониазиду, по нашим результатам, выше таковой к стрептомицину, что отличается от данных других авторов [8]. Аоля лекарственной устойчивости к препаратам резервного ряда была значительно ниже: канамицину - у 19 $(18,6 \pm 3,8 \%)$, этионамиду - у $6(5,9 \pm 2,3 \%)$, офмоксацину у $4(3,9 \pm 1,6 \%)$, ПАСК - у $2(2,0 \pm 1,4 \%)$ больных.

Изучение первичной лекарственной устойчивости МБТ по количеству препаратов установило, что она наиболее часто встречалась к трём противотуберкулезным препаратам - у $25(24,5 \pm 4,3 \%)$ больных, к четырём - у 20 (19,6 6 3,9\%), к двум - у $16(15,7 \pm 3,6 \%) ;$ значительно реже к пяти - у 5 $(4,9 \pm 2,1 \%)$, к шести и семи - по $1(1,0 \pm 1,0 \%)$.

\section{Заключение}

Таким образом, частота первичной мекарственной устойчивости МБТ к противотуберкулезным препаратам у больных туберкулезом легких в пенитенциарных учреждениях Красноярского края очень высока и составляет $70,6 \pm 4,5 \%$, а в ее структуре преобладает множественная лекарственная устойчивость, которая определяется практически у каждого второго больного $(48,2 \pm 5,0 \%)$; реже встречаются поли- $(15,7 \pm 3,6 \%)$ и монорезистентность $(3,9 \pm 1,6 \%)$. Особенно высока доля первичной лекарственной устойчивости МБТ к препаратам основного ряда: изониазиду $-63,7 \pm 4,8 \%$, стрептомицину $-55,9 \pm 4,9 \%$, рифампицину $-53,9 \pm 4,9 \%$, что делает невозможным применение режимов химиотерапии с использованием этих препаратов более, чем у половины впервые выявленных больных туберкулезом мегких из числа спецконтингента. Аия лечения данной категории больных следует использовать препараты резервного ряда с целью предотвращения развития индукции лекарственной устойчивости МБТ к большему количеству препаратов, в связи с чем необходимо применение ускоренных методов определения лекарственной чувствительности МБТ. С учетом высокой частоты множественной лекарственной устойчивости МБТ и Аля повышения эффективности лечения впервые выявленных больных туберкулезом легких в туберкулезной больнице-1 МСЧ №24 ФСИН России в течение Авух лет в комплексной терапии широко используются такие методы как лимфотропное введение противотуберкулезных препаратов, клапанная бронхоблокация, наложение пневмоперитонеума.

\section{Аитература}

1. Жукова Е.Н., Макаров И.Ю. Эпидемиологические и патоморфологические особенности лекарственно- 
устойчивого туберкулеза легких в современных условиях // Аальневосточный медицинский журнал. - 2012. № 1. - C. 134-136.

2. Золотарева А.В., Золотарев Ю.В., Стратулат А.Ю. Структура первичной лекарственной устойчивости штаммов микобактерий туберкулеза у впервые выявленных больных туберкулезом легких // Инфекционные болезни. - 2014. - Т. 12, № 1. - С. 108.

3. Кононец А.С. лекарственно-устойчивый туберкулез легких в исправительных учреждениях уголовно-исполнительной системы // Проблемы туберкулеза и болезней мегких. - 2008. - № 12. - С. 60-63.

4. Кононец А.С., Хорошилова Н.Е., Голубева А.И. Туберкулез легких с множественной лекарственной устойчивостью возбудителя к основным и резервным препаратам // Эпидемиология и инфекционные болезни. - 2010. № 1. - С.24-29.

5. Корецкая Н.М., Аевина Е.Б., Пыринова Н.В. Биологические свойства микобактерий туберкулеза у больных в пенитенциарных учреждениях // Сибирское медицинское обозрение. - 2009. - № 2. - С. 65-68.

6. Маркелов Ю.М. Клинико-эпидемиологические особенности туберкулеза с множественной мекарственной устойчивостью микобактерий и причины его распространения в Карелии // Туберкулез и болезни мегких. 2011. - № 8. - C. 11-17.

7. Мишин В.Ю. Туберкулез легких с лекарственной устойчивостью возбудителя: учебное пособие. - М.: ГЭОТАР-Медиа, 2009. - 208 с.

8. Мякишева Т.В., Гуденков М.А. Эпидемиологическая ситуация и динамика лекарственной устойчивости микобактерий туберкулеза в Смоленской области за 20052010 гг. // Эпидемиология и инфекционные болезни. 2012. - № 1. - C. 4-9.

9. Сапожникова Н.В., Яковчук А.А., Чернохаева И.В., Павлова М.В., Арчакова А.И., Старшинова А.А., Журавлев В.Ю. Влияние ранних методов диагностики множественной лекарственной устойчивости на эффективность лечения пациентов с туберкулезом органов дыхания // Инфекционные болезни. - 2014. - Т. 12, № 1. - С. 273-274.

10. Туберкулез в Российской Федерации 2011 год: аналитический обзор статистических показателей, используемых в Российской Федерации и в мире. - М.: Триада, 2013. - 280 c.

\section{References}

1. Zhukova E.N., Makarov I.Yu. Epidemiological and pathomorphological characteristics of drug-resistant pulmonary tuberculosis in modern conditions // Far East Medical Journal. - 2012. - № 1. - P. 134-136.

2. Zolotareva L.V., Zolotarev Yu.V., Stratulat A.Yu. The structure of primary drug resistance in Mycobacterium tuberculosis strains in newly diagnosed patients with pulmonary tuberculosis // Infectious Diseases. - 2014. - Vol. 12, № 1. - P. 108.
3. Kononets A.S. Drug-resistant tuberculosis in penal institutions of the penitentiary system // Problems of Tuberculosis and Lung Disease. - 2008. - № 12. P. 60-63.

4. Kononets A.S., Khoroshilova N.E., Golubeva L.I. Pulmonary tuberculosis with multidrug-resistant pathogen to primary and secondary drug // Epidemiology and Infectious Diseases. - 2010. - № 1. - P. 24-29.

5. Koretskaya N.M., Levina E.B., Pyrinova N.V. Biological properties of Mycobacterium tuberculosis in patients at the penitentiary institutions // Siberian Medical Review. 2009. - № 2. - P. 65-68.

6. Markelov Yu.M. Clinical and epidemiological features of tuberculosis with multidrug resistance of mycobacteria and the reasons for its spread in Karelia // Tuberculosis and Lung Disease. - 2011. - № 8. - P. 11-17.

7. Mishin V.Yu. Pulmonary tuberculosis with drug-resistant pathogen: a tutorial. - M .: GEOTAR Media, 2009. $208 \mathrm{p}$.

8. Myakisheva T.V., Gudenkov M.A. The epidemiological situation and the dynamics of drug resistance of Mycobacterium tuberculosis in the Smolensk region for 2005-2010 years. // Epidemiology and Infectious Diseases. - 2012. - № 1. P.4-9.

9. Sapozhnikova N.V., Yakovchuk A.A., Chernokhaeva I.V., Pavlova M.V., Archakova L.I., Starshinova A.A., Zhuravlev V.Yu. Effect of early diagnostic methods of multidrug resistance on the effectiveness of treatment the patients with pulmonary tuberculosis // Infectious Diseases. - 2014. - Vol. 12, № 1. - P. 273-274.

10. Tuberculosis in the Russian Federation in 2011: an analytical review of statistical indicators used in the Russian Federation and in the world. - M .: Triada, 2013. - 280 p.

\section{Сведения об авторах}

Корецкая Наталия Михайловна - уоктор меgицинских наук, профессор, завеяующая кафеgрой туберкулеза с курсом ПО, ГБОУ ВПО Красноярский государственный меgицинский университет имени проф. В.Ф. Войно-Ясенецкого МЗ РФ.

Agрес: 660042, г. Красноярск, ул. 60 лет Октября, g. 26; тел.8(391)2617682; e-mail:kras-kaftuber@mail.ru.

Элярт Влаgимир Феликсович - начальник МСЧ-24 ФСИН России.

Agpec: 660048, г. Красноярск, ул. Маерчака, 48, Меgико-санитарная часть №24 Феgеральной службы исполнения наказаний России; тел. 8 (391) 2211004; e-mail:ktb1-zakup@yandex.ru.

Белоусова Юлия Николаевна - врач-бактериолог туберкулезной больницы-1 МСЧ-24 ФСИН России.

Agрес: 660048, г. Красноярск, ул. Маерчака, 48, Меgико-санитарная часть № 24 Феgеральной службы исполнения наказаний России; тел. 8 (391) 2211004 e-mail: ktb1-zakup@yandex.ru.

\section{Authors}

Koretskaya Nataliya Mikhailovna-Dr.Med.Sc., Professor, Head of the Department of Tuberculosis, Krasnoyarsk State Medical University named after Prof. V. F. VoinoYasenetsky.

Address: 26, 60 years of October Str., Krasnoyarsk, Russia, 660042; Phone: 8(391)2617682; e-mail: kras-kaftuber@mail.ru.

Elyart Vladimir Feliksovich - Head of MSCh-24 FSIN of Russia.

Address: 48, Maerchak Str., Krasnoyarsk, Russia, 660048; Phone: 8 (391) 2211004; e-mail: ktb1-zakup@yandex.ru.

Belousova Yulia Nicolaevna - Physician-Bacteriologist of Tuberculosis Hospital-1, MSCh-24 FSIN Russia.

Address: 48, Maerchak Str., Krasnoyarsk, Russia, 660048; Phone: 8 (391) 2211004; e-mail:ktb1-zakup@yandex.ru. 